\title{
ESR2 Positive
}

National Cancer Institute

\section{Source}

National Cancer Institute. ESR2 Positive. NCI Thesaurus. Code C159159.

An indication that expression of ESR2 has been detected in a sample. 